\title{
Epidemiological Study of Sickle Cell Disease in Tribal Children in Katihar District.
}

\author{
Dr. Avinash Kumar Sahay,M.D.(Paed) ${ }^{1}$, Dr. Ghazi Sharique Ahmad, M.D ${ }^{2}$. \\ ${ }^{I}$ Department Of Paediatrics ,Katihar Medical Collage, Katihar. Bihar \\ ${ }^{2}$ Assistant Professor, Department Of Paediatrics, Katihar Medical Collage, Katihar, Bihar.
}

\begin{abstract}
:
Observation: This study was done to know the incidence of Sickle Cell Disease in the tribal population of Katihar district of Bihar.

Method: Tribal patients coming in the OPD of pediatrics department of Katihar Medical College, Katihar for different complains were screened through proper history, clinical examination and blood investigations including electrophoresis and sickling test. And incidence of sickle cell disease was calculated.

Observation: About $10 \%$ of the patients were found to be having different haemoglobinopathy and in which $6 \%$ were having sickle cell disease.

Conclusion: The incidence of different haemoglobinopathy among tribal population of this area was very high. So if antenatal screening programme is introduce in this area it will surely help in reducing the burden of this disease.
\end{abstract}

Keywords: SCD- sickle cell disease, SCA-sickle cell anemia; SCT- sickle cell trait.

\section{Introduction}

In modern science structural study o hemoglobin paved the path for treatment and prevention of any disease. It was no other than Dulop et al and Mazumdar et al (1952) who reported first case of "Sickle cell anemia " among the laborers originating from tribal community of Orissa and Bihar. As very small work has been done to know the incidence of SCA in the tribal population of Katihar district area so this work is taken to know about its incidence in this area so that screening programme can be started in the target group to reduce the burden of this disease.

\section{Material And Method}

This study was done in the paediatric unit of Katihar Medical College, Katihar during July 2012 and Dec. 2012. Total 130 tribal children attending the outdoor department of pediatrics for different problems were taken into the study. All these children were gone through detail family history, clinical examination, and blood, urine and stool examination. Out of 130 children 65 children who had pallor along with either hepatomegaly or splenomegaly or enlarged lymph node or all underwent the special test meant for diagnosing haemoglobin abnormalities as sickling test, hemoglobin electrophoresis and osmotic fragility.

\section{Observations}

To explore the incidence of SCA and SCT in 130 children of age group 2 years to 7 years belonging to different tribal groups of Katihar district were taken into study irrespective of age, sex, and their complains. All these children gone through full family history, clinical examinations and blood, urine and stool examinations. Special tests i.g. sickling test, Hb-electrophoresis and osmotic fragility test were also done in a selected group. Out of 12 cases of hemoglobin abnormalities 2 case of SCA and 6 cases of SCT were detected on the basis of sickling test and $\mathrm{Hb}$-electrophoresis.

Table-1 Table Showing Presenting Symptoms Of Patients At Opd And Major Signs In Them :

\begin{tabular}{|l|l|l|}
\hline Presenting Symptoms \& Signs & No. Of Patients & Persentage \\
\hline 1. Fever & 74 & 56.9 \\
\hline 2.Pallor & 90 & \\
\hline 3.Poor Weight Gain & 56 & 69.2 \\
\hline 4.Protubrant Abdomen & 27 & 43 \\
\hline 5.Mongloid Facies & 3 & 20.7 \\
\hline 6.Haemic Murmur & 25 & 2.3 \\
\hline 7.Lympadenopathy & 48 & 19.2 \\
\hline
\end{tabular}




\begin{tabular}{|l|l|l|}
\hline 8.Haepatomegaly & 25 & 19.2 \\
\hline 9. Splenomegaly & 15 & 11.5 \\
\hline & & \\
\hline
\end{tabular}

Table is showing that children with different complain was taken into study. Majority of the children were either having fever (56.9\%) or pallor(69.2\%) at presenatation.43\% had poor weight gain. Major clinical signs were enlarged lymph node $(36.9 \%)$, hepatomegaly $(19.2 \%)$, splenomegaly $(11.5 \%)$ and mongloid facies $(2.3 \%)$

Table 2 Showing Blood Pictures Of All The Children Having Haemoglobonopathy

\begin{tabular}{|l|l|l|l|l|l|l|l|l|l|}
\hline & SCT 1 & SCT 2 & SCT 3 & SCT 4 & SCT 5 & SCT 6 & SCA 1 & SCA 2 & $\begin{array}{l}\text { Other } \\
\text { 4cases }\end{array}$ \\
\hline 1Hb & 9.4 & 8.3 & 9.0 & 7.6 & 9.2 & 8.8 & 6.9 & 7.2 & $\begin{array}{l}3.2 \\
\text { to }\end{array}$ \\
\hline 2Reticulocyte & 2.2 & 3.1 & 2.8 & 2.6 & 3.3 & 2.7 & 5.9 & 5.1 & $\begin{array}{l}5.8 \text { to } \\
6.8\end{array}$ \\
\hline 3Anisocytosis & - & - & - & - & - & - & + & + & + \\
\hline 4Target Cell & - & - & - & - & - & - & - & - & + \\
\hline 5Sickle Cell & - & - & - & - & - & - & + & + & - \\
\hline 6Sickling test & + & + & + & + & + & + & + & + & - \\
\hline 7Electrophoresis & AS & AS & AS & AS & AS & AS & SS & SS & AF \\
\hline
\end{tabular}

Table shows that haemoglobin of all the children having different haemoglobinopathy were less than 10. In SCD it was around 7.2 gms while in other groups it was even less than that. All the children having AS or SS pattern at electrophoresis have sickle cell and sickling test positive.

Table 3 table showing electrophoretic pattern of the cases :

\begin{tabular}{|l|l|l|l|l|l|}
\hline Total No. Of Cases Of Haemoglobin Disorder & \multicolumn{4}{|l|}{ Electrophoresis pattern } \\
\cline { 2 - 6 } & SS & AS & AF & Other \\
\hline 12 & 2 & 6 & 4 & Nil \\
\hline
\end{tabular}

This table shows that out of 12 patients having haemoglobin problems 2 have SS pattern, 4 have AS pattern and 4 have AF pattern. No other haemoglobin abnormalities were detected in the taken sample.

Table 4 showing persentage of alkali resistant haemoglobine (hbf) in the cases :

\begin{tabular}{|l|l|l|}
\hline Types Of Cases & No. Of Cases & Persentage \\
\hline Sickle Cell Anemia & 1 & Less Than 2 \\
\hline Sickle Cell Trait & 3 & Less Than 2 \\
\hline Thalassaemia Type & 2 & $24 \%$ \\
\hline
\end{tabular}

Scrutiny of the above table indicates that foetal haemoglobin was not raised in sickle cell group as seen in other group.

Table 5Table Showing Incidence Of Scd And Other Haemoglobinopathy

\begin{tabular}{|c|c|c|c|c|c|c|c|c|}
\hline $\begin{array}{l}\text { Total no. of } \\
\text { cases }\end{array}$ & \multicolumn{2}{|c|}{ SCA } & \multicolumn{2}{|c|}{ SCT } & \multicolumn{2}{|c|}{$\begin{array}{l}\text { Other } \\
\text { heamoglobinopat } \\
\text { hy }\end{array}$} & \multicolumn{2}{|c|}{$\begin{array}{l}\text { Other } \\
\text { diseases }\end{array}$} \\
\hline 130 & No & $\%$ & No. & $\%$ & No. & $\%$ & No. & $\%$ \\
\hline & 2 & 1.5 & 6 & 4.6 & 4 & 3 & 28 & 21 \\
\hline
\end{tabular}

\section{Discussion}

If we analyze the table above we clearly see that incidence of SCD is high in the present study. Out of total 130 children complete haemoglobinopathy evaluation was done in 64 of them who after clinical examination suspected to be a case of haemoglobin disorder. And in these 64 children 8 were case of SCD (total haemoglobin disorder 12 ). Table 2 gave details account of hematological finding in both the groups. In SCT these finding are in normal range while in SCA case there were marked poikilocytosis, ovalocytosis and very high reticulocyte count. This finding is same as seen in the study of Wintrobe at el. Another table showed that sickling was demonstrated in all the cases but in patients showing traits nearly $20-25 \%$ showed sickling after 2 hrs while in SCA cases nearly $80-85 \%$ showed sickling in 2 hrs. It is because trait has both $\mathrm{HbS}$ and $\mathrm{HbA}$ while SCA has only HbS. 
Summary

1. Cases of SCT are found in all the age group with preponderance in male.

2. In SCT case sickling did not start immediately. But after 2 hrs only $20-25 \%$ cell showed sickling and after 24 hrs all showed sickling.

3. Electrophoresis showed AS pattern in SCT cases and SS pattern in SCA cases.

4. Hematological data showed normochrome normocytic anemia in all the cases. Similarly sickling test is positive in all the cases.

5. Incidence of SCD in the adivasi of katihar district is high but still less than the tribal population of other state.

\section{Conclusion}

Analyzing the high incidence of hemoglobin disease in this area, it has been suggested that if antenatal screening programme and marriage counseling are promoted in this area incidence will go down significantly.

\section{Biblipgraphy}

[1]. Reed D C, Wllam T M, Glawin MT- Sickle cell disese. Lancet 2010;376:2018.31

[2]. Singh KS, Calcutta- Anthropological survey of India; 1992. People of India.

[3]. Kaur M, Das GP, Verma IC. Sickle cell trait and disese among tribal community in orrisa, Madhya Pradesh, Kerala. India J Med Res- 1997;55:104-9

[4]. Kle SL, Lingojwar DP- Epedimiology of sickle cell disorder in state of Maharastra. Iia J Hum Gincet 2002; 3:161.

[5]. Collin, F.S.; Weissman S.M. : The molelicular genetics of human haemoglobin Prog. 31;315 1985

[6]. Alter,B.P. : Blood 64:329 1984

[7]. Bunn. H.E.; Forget, S.S. : Haemoglobin :Molecular genetics and clinical aspact. phidalphia 1986

[8]. E mbury,S. : The clinical pathophysioloy of sickle cell disease. Annu. Rev. Med. 37:36 1986 